\title{
Inside Shareholders' Effective Tax Rates and Dividends
}

\begin{abstract}
Using information collected from the Swedish tax authorities, we calculate insiders' actual effective tax rates on dividends. With this unique dataset, we find a significant negative cross-sectional relationship between insiders' effective tax rates and dividend payout. This result is consistent with a tax induced clientele effect for dividends. We also look at the impact of large block trades on dividends. We find that when insiders with zero effective taxes sell blocks, subsequent dividend payments are significantly more likely to decrease. This provides evidence that large shareholders are adjusting dividends for their individual tax situations.
\end{abstract}

December 2007

Key words: Dividends, Taxes, and Insider ownership

JEL classification: G32, G35 


\section{$1 \quad$ Introduction}

Researchers have extensively examined whether shareholders form clienteles based upon taxed-induced preferences for dividends. Ceteris paribus, the higher the tax rate paid on dividends, the lower the preferred dividend payout. Furthermore, when a controlling shareholder is in a high tax bracket, he may set a relatively low dividend payout. PerezGonzales (2003) finds that for firms with large shareholders, changes in tax rates affect firm dividend payout policy. However, Barclay, Holderness, and Sheehan (2007) (henceforth BHS) look at block trades from individuals (who are taxed on dividend income) to corporations (who are not taxed on dividend income) and do not find evidence that corporate blockholders use their power to increase dividends. They conclude that taxes are not an important factor in a corporation's decision to receive dividend income.

We have collected a unique dataset from the Swedish tax authorities of the actual taxes paid by individual large shareholders. Although the tax code in Sweden is not identical to the US tax code, the average tax rate on dividends is lower for corporations than for individuals in both Sweden and the US. Also, like the US tax code, the Swedish tax code allows deductions against dividend income. As a result, for the insiders in our study, the effective tax rates paid on their dividend income varies from $0 \%$ to a maximum rate of $30 \%$, with a mean and median of $17 \%$ and $30 \%$, respectively.

A significant drawback of previous studies examining the relationship between dividend policy and marginal tax rates is that the actual personal tax rate of individual shareholders is generally unknown. As a result, researchers need to make assumptions about individuals’ personal tax rates. For example, since corporations are not taxed on dividend income in the US, BHS assume that all corporations are in a lower tax bracket than individuals. However, individuals are allowed to reduce taxable dividend income 
through various deductions. Thus there are instances in which the effective tax rate on dividends of individuals is also zero. ${ }^{1}$ In the BHS sample, any individual shareholder with an effective tax rate on dividends of zero would be miss-classified. This would make it difficult to find a tax-induced effect on dividends even if one actually existed.

Using the actual personal tax rates of large individual investors, we avoid the potential miss-classification problem discussed above. As a result, we are able to conduct more powerful tests of the relationship between dividend payout and taxes. We examine two questions: First, do shareholders form clienteles based upon their tax-induced preferences for dividends? ${ }^{2}$ Second, do large shareholders receive private benefits of control by using their power to directly influence dividend payout for tax reasons (Shleifer and Vishny (1986))?

We find a significant negative cross-sectional relationship between insiders’ effective tax rates and dividend payout. This result is consistent with a tax induced clientele effect for dividends. Although the average (and median) insider coalition has effective control with approximately $40 \%$ of the votes, this result cannot be used to indicate whether insiders use their power to actively manage dividends. We would find a negative relationship between insiders’ effective tax rates and dividend payment, whether insiders lowered dividend payout to reduce their effective tax rates or instead first set dividend policy for reasons unrelated to taxes and then adjusted their deductions to reduce their effective tax rate. ${ }^{3}$

\footnotetext{
${ }^{1}$ Peterson, Peterson, and Ang (1985) showed that in the US for their study period the estimated marginal tax rate on dividends was $40 \%$ while the effective rate was $30 \%$.

${ }^{2}$ Miller and Scholes (1978) and Brennan and Thakor (1990) have examined the effect of taxes on an insider shareholder's preference for capital gains or dividends.

${ }^{3}$ Another advantage of our study is that we do not need to consider whether the insiders had the firm buyback shares rather than pay dividends to avoid taxes, since share buy backs were against Swedish corporate law for the time of our study.
} 
To address the question of causality, we perform a second set of tests of the impact on dividends of large block trades. If insiders set dividend policy for personal tax reasons, we expect that when blocks are traded to lower effective tax rate investors, firm dividends should increase in the years following the block trade. However, we find that when block sellers with the highest effective tax rate sell their blocks, there is no significant difference in the subsequent dividend yields, payout or probability of dividend cuts. These results imply that being able to protect dividends from taxes is not sufficient to induce large shareholders to increase dividends. Furthermore, these results are consistent with BHS, who found that when individuals sold blocks to corporations, which they assumed had lower marginal tax rates, dividends were not affected.

Alternatively, when blocks are traded to investors who have higher effective tax rates, dividends should decrease. We find that when insiders with effective taxes of zero sell blocks, subsequent dividend payments are significantly more likely to decrease. This provides evidence that large (controlling) shareholders are adjusting dividends to optimize their individual tax situations. Although BHS examine block trades from individuals to non-taxed corporations, they do not examine the reverse: block trades from non-taxed corporations to individuals.

In summary, highly taxed controlling shareholders reduce dividends to avoid paying taxes. On the other hand, controlling shareholders with low marginal tax rates do not automatically increase dividends just because they will not pay taxes on their dividends.

In related work, Miller and Scholes (1978) and Brennan and Thakor (1990) have examined the effect of taxes on whether an insider shareholder prefers for capital gains or dividends. Graham and Kumar (2005) find that retail investors with higher incomes (and presumably higher tax rates on dividends) prefer lower dividend paying stocks. 
The dividend studies are not limited to individual preferences. Eckbo and Verma (1994) hypothesized that a firm's dividend policy was a result of consensus building among heterogeneous shareholders. Also, Lie and Lie (1999) showed that as institutional ownership of shares increases, a firm's dividend policy is more closely associated with shareholder preferences.

In the next section we discuss the Swedish tax code for dividend income. We describe the data and define the variables in section 3. In section 4, we report our empirical results. Finally, in section 5, we present our conclusions.

\section{Swedish Tax Code}

In Sweden, individuals, corporations and financial institutions are each subject to different rules and tax rates on dividend income. For individuals, for our study period 1991 to 1995, dividends, capital gains and interest income were all classified as capital income. All capital losses from the sale of shares and other financial instruments of a similar kind could be subtracted from capital gains and dividends on similar instruments. Also, as shown in Table 1, the tax rate for dividend income for all types of taxable entities for the years 1991 to 1995 remained constant with the exception of $1994 .^{4}$

For corporations, all taxable income of any kind is considered income from trade and business and is then taxed at a flat rate. This rate was 30\% from 1991 to 1993 and 28\% for 1994 and 1995. In order to avoid double-taxation of dividend income, dividend income is generally tax-free for holding companies and for other corporations which hold a vote portion of at least $25 \%$ in the dividend-paying company. A shareholding of less than $25 \%$ 
of the votes is considered a capital investment, and the dividend income is taxed as ordinary business income.

Open- and closed-end investment funds are not taxed on capital gains. Although dividend income is taxable, investment funds may deduct dividends paid to investment fund shareholders against the investment fund's dividend income as long as there is no fiscal deficit (Lodin et al., 1999, pp 433-436). Thus, depending on how much the fund distributes to the investors in the fund, the tax rate on received dividends varies between zero and $30 \%$. However, dividends paid by investment funds to individuals are taxed at the personal level.

\section{Sample and Variable Definitions}

In this section we describe our sample of panel data and define the variables used for our empirical tests.

\subsection{Sample}

We begin with A-listed firms (the main list) on the Stockholm Stock Exchange, 1991-1992. These are the most traded and, with few exceptions, the largest firms in Sweden. We collected shareholder data from the official lists of a public authority (VPC) and from Sundqvist (1991 and 1992). For each firm we identified the insiders (managers and board members), with the largest fraction of voting rights (if it is larger than 1\%) and gathered information on the equity of insiders. When defining the insider's voting rights, we use the same principle for grouping shareholders into coalitions as Sundqvist (1991 and 1992). Family members, family-controlled firms and family foundations are treated as one

\footnotetext{
${ }^{4}$ In 1994 the conservative government temporarily lowered the top marginal rate on dividends to $0 \%$ and $12.5 \%$ on capital gains. However, there were severe restrictions on the amount of dividends that firms could
} 
coalition. The insider's ownership of equity is, on the other hand, based solely on his ownership in the firm; this ownership may be either direct or indirect.

We then collected tax data from the tax authorities for these insiders. Insiders, who work all or most of their time abroad, are not taxed in Sweden and are therefore eliminated from the sample. This left us with a total of 110 insiders and firms, 59 and 51 in 1991 and 1992 respectively. For all the firms in the sample, we collected financial characteristics from the FINDATA base. ${ }^{5}$

For our second set of tests, we also need data for a pre-period (1988 to 1990) and a post-period (1993 to 1995) in order to estimate changes in dividend payments. Forty-six firms are present in both the 1991 and 1992 samples, leaving us with 64 firms. Five additional firms’ financial data were missing for the years before or after 1991 or 1992. This narrowed our sample for these tests from 110 to 59 firms (427 firm years) due to overlapping observations and missing data.

\subsection{Variable for Tax Rates on Dividends}

In order to calculate the effective tax rate for individuals, ETR, we collected taxable capital income (capital income after deductions) and received dividends. The Swedish tax authorities make public a one-page document for every tax-payer, which contains net taxable capital income, salary income and taxable wealth. Before 1997, individual tax data could be collected and entered into a database. In 1997 the Swedish privacy laws became much stricter, and it is no longer permissible to collect and build databases for individuals (unless each individual included in the database signs an agreement). Our initial data

\footnotetext{
distribute.

${ }^{5}$ There were 124 (112) firms listed on the A-list in January 1991 (1992). Thus, our sample includes approximately half of the A-listed firms. Firms are not included in the sample when i) insiders were not being taxed in Sweden, ii) there is no substantial insider ownership in the firm, and iii) we have not been able to
} 
collection and data-base construction were done before the stricter privacy laws. In order to conform to the present Swedish law, our data-set has been made anonymous.

Received dividend is the amount of dividends (in thousands SEK) paid in the taxable year to the largest insider shareholder in the firm. We estimate received dividend as the dividends paid per share during the year times the number of shares held. ${ }^{6}$ We calculate taxable dividend as follows:

(1) When net capital income is greater than or equal to received dividend, the entire received dividend is taxable; therefore, received dividend equals taxable dividend.

(2) When net capital income is negative, none of the received dividend is taxed; therefore, taxable income is 0 .

(3) When net capital income is less than dividend received, but greater than zero, some, but not all, of the dividends are taxed. In this case, we set taxable dividend income equal to net capital income.

The ETR is estimated by classifying the data in the same manner as for the taxable dividend calculations.

(1) When capital income is greater than or equal to received dividend, the entire received dividend is taxable, so we assign a $30 \%$ ETR.

(2) When net capital income is negative, none of the dividend income is taxed; therefore, we assign an ETR of $0 \%$.

(3) When the capital income is less than dividend received, but greater than zero, some, but not all, of the dividends are taxed. In this case we calculate the ETR as:

\section{$E T R=[$ Net Capital Income $/$ Dividend Received $] * 30 \%$}

The ratio [Net Capital Income / Dividend Received] is the portion of dividends that are taxed. For example, if Net Capital Income is one-half of Dividend Received, then one-half of the dividends are taxed. If the marginal tax rate on dividend income is $30 \%$ and half is taxed, the tax rate is, in effect, $15 \%$.

collect financial characteristics from the FINDATA base. Our sample firms are not significantly different than the other A-listed firms in terms of a large set of firm characteristics. 
Table 2 shows a breakdown of the effective tax rates for our sample. Some of the insiders in our sample have sufficient deductions to completely protect their dividend income from any tax liability. As a result, for the insiders in our study, the effective tax rates paid on their dividend income varies from $0 \%$ to a maximum rate of $30 \%$. The average and median ETR on received dividend for our sample are $17.4 \%$ and $30 \%$, respectively. Also, as shown in the header of Table 2, we have a bimodal distribution of ETRs where $28 \%$ of insiders have $\mathrm{ETR}=0 \%$ and $51 \%$ have $\mathrm{ETR}=30 \%$. Therefore, we make two additional dummy variables for our tests. First, for insiders who do not pay any taxes on dividends we have,

$$
\text { Insider } \begin{aligned}
E T R=0 \text { Dummy } & =1, \text { if insider has a zero ETR, } \\
& =0, \text { otherwise. }
\end{aligned}
$$

Next, for insiders with the highest effective tax rate of $30 \%$ we have,

$$
\begin{aligned}
\text { Insider ETR=30 Dummy } & =1, \text { if insider has a 30\% ETR, } \\
& =0, \text { otherwise. }
\end{aligned}
$$

For our block trade variables, we need to define a block trade. Of our sample of 59 different insider ${ }^{7}$ controlled firms during the 1991 and 1992 period, 21 were involved in control block changes between 1991 and 1995. A control block trade is defined as a block trade of at least $5 \%$ of firm equity or voting rights. We assume that a block trade of at least $5 \%$ is sufficient to influence a firm's dividend policy. We collect the block trade information from Sundqvist (1991 to 1993) and from Sundin and Sundqvist (1994 and 1995). These sources document all major ownership changes.

\footnotetext{
${ }^{6}$ Dividends are paid once a year, typically in the spring, based upon ownership, approximately 10 days before the annual meeting. We measure number of shares in January of the year.

${ }^{7}$ We identify the insider shareholders in our sample if they hold at least $1 \%$ of firm voting rights. We are typically not able to identify block trades by insiders holding less than $5 \%$ of firm equity or voting rights.
} 
Using our definitions of block changes and effective tax rates, we make some additional variables. First, to compare our results to BHS, we classify block traders into two groups: individuals and institutions. The group classified as individuals are the insiders in our sample involved in block trades during the 1991 to 1995 period. The institutional block traders consist of three types: corporations, open-end investment funds and closedend investment funds. As we pointed out earlier, for all three types of institutions, the effective tax rates are between 0 and $30 \%$, but are typically lower than for individual shareholders, as discussed in section 2. Using this distinction, we construct the following dummy variables:

Insider Dummy = 1, the years after an insider acquired a block from an institution, $=0$, otherwise

Institutional Dummy = 1, the years after an institution acquired a block from an insider, $=0$, otherwise.

Using insiders' actual effective tax rates, we separate inside sellers with an effective tax rate of zero from the other insiders. ${ }^{8}$ Thus we define the following dummy variable:

Insider ETR=0 Sell Dummy $=1$, the years after an insider with a zero effective tax rate on dividends sold his/her block, $=0$, otherwise.

Next, to set off inside sellers with the highest effective tax rate of $30 \%$ we have,

Insider ETR=30 Sell Dummy = 1, the years after an insider with a 30\% effective tax rate on dividends sold his/her block, $=0$, otherwise.

\subsection{Dividend Payment Variables}

\footnotetext{
${ }^{8}$ It may be interesting to break the buyer group into sub-samples of individuals and institutions. Unfortunately those sub-sample sizes aren't large enough to produce meaningful results.
} 
We construct four variables to measure the dividend payments of firms. Our first measure is

Dividend Yield $=$ Total dividends paid during the year divided by market value of equity at beginning of year

Our second measure of dividend payments is

Payout Ratio $=$ total dividends paid during year divided by accounting earnings

If dividends are paid but accounting earnings are negative, Payout Ratio is set to one. If dividends are larger than accounting earnings, Payout Ratio is set to one.

There are some possible weaknesses of the Dividend Yield and Payout Ratio variables. For example, Dividend Yield may increase or decrease when the stock price changes, but this may not result in any change in actual dividend payments. Similarly, Payout Ratio may change with an increase or decrease in profits without any change in dividend payments. Also, Dividend Yield and Payout Ratio may vary by industry and other factors.

In order to alleviate the problems associated with changing stock prices and profits, we use two more variables which are directly related to changes in the actual level of dividends. Our third variable, Dividend Increase, looks at whether there are increases in dividends during the years following a block trade.

Dividend Increase $\quad=1$, if the firm increases the dividend the year following a block trade, $=0$, otherwise

We follow the sample firms from 1988 to 1995 . The Dividend Increase dummy is equal to one each year the firm increased dividends. Thus, if a firm increased dividends every year, the variable would be equal to one for all years. 
Since it is very unusual for firms to actually decrease dividends per share, our next dummy variable, Dividend Decrease, allows us to perform very strict tests of the effect of selling blocks from low to high effective tax rate shareholders.

Dividend Decrease $\quad=1$, for all years after a dividend decrease until dividends are as high or higher than before the dividend decrease, $=0$, otherwise

\subsection{Control Variables}

We need to control for other factors that have been found to affect dividend policy. Larger more mature firms typically pay higher dividends. Therefore, to control for firm size we use: Size $=$ book value of total assets in Million SEK. Both dividend payments and interest payments on debt reduce free cash flow, thereby reducing agency conflicts (Jensen (1986)). As a result we control for firm leverage using: Leverage = Book Value of Debt / Book Value of Total Assets. Also, since high growth firms are more likely to reinvest profits rather than pay dividends, we control for firm growth by, Sales Growth = the annual change in the firm's total sales. ${ }^{9}$ An outside blockholder may not have the same tax induced preferences as insiders. In addition, if increased dividends reduce agency costs, a substantial outside stakeholder may pressure managers to increase dividends. Also, Lie and Lie (1999) show that managers are more sensitive to other shareholders' tax preferences, when institutions hold a large block of shares. Therefore, we use the following variable,

\footnotetext{
Outside Block $=1$, if there is an outsider with at least 10 percent of the votes $=0$, otherwise. ${ }^{10}$
}

\footnotetext{
${ }^{9}$ Faccio, Lang and Young (2002) used the same control variables in their study of dividend payments. We also ran our tests using the same control variables as BHS without any material change in our results. ${ }^{10}$ The vast majority of outside blockholders are institutions. Splitting the Outside Block variable into an institutional block dummy and an individual block dummy does not change our results.
} 
We include six industry dummies roughly based on one-digit SIC codes because some industries are known to pay higher dividends as for example the utility industry. ${ }^{11}$ Also, we insert year dummies since we need to control for economic and market factors, such as a recession, that would affect a firm's dividend policy. In Table 2 we present summary statistics for the variables used in the empirical tests. We also report the vote fraction of the insiders' coalitions. The average and median insider coalition controls $40 \%$ of the votes. Thus, the typical insider has the opportunity to influence firm dividend policy. ${ }^{12}$

\section{$4 \quad$ Empirical Results}

In this section we present the results of our test of the relation between managers' personal tax rates and the firm's dividend policy.

\subsection{Ordinary Least Squares Results}

We begin our tests by examining the cross-sectional relationship between dividend payout and insiders' effective tax rates. A negative relationship between dividend payout and effective tax rates would provide evidence of a tax-induced clientele effect. For our cross-sectional regressions, we estimate the following equation:

$$
\begin{aligned}
\text { DIVIDEND }_{i t}= & \beta_{0}+\beta_{1} \text { ETR }_{i t}+\beta_{2} \text { Lsize }_{i t}+\beta_{3} \text { Leverage }_{i t}+\beta_{4}{\text { Sales } \text { Growth }_{i t}} \\
& +\beta_{5} \text { Outside Block }_{i t}+\text { Industry }_{j}+\text { Year }_{t}+\varepsilon_{i t}
\end{aligned}
$$

Our dependent variable, DIVIDEND $i$, is the dividend payment of firm i at time t. We use Payout Ratio $_{\text {it }}$ and Dividend Yield it $_{\text {a }}$ as proxies for dividend payment in the regression equation (1). $E T R_{i t}$ is the effective tax rate for investor $\mathrm{i}$ at time t. We include control

\footnotetext{
${ }^{11}$ The six industries are Heavy industry, Technical manufacturing, Construction, General services, Transportation, and Commercial services.

${ }^{12}$ Including the voting fraction of the insider's coalition as an independent variable in our tests does not affect the results, and the vote variable is insignificant in all regressions.
} 
variables for size, leverage, sales growth and outside blockholders. Industry $y_{j}$ and Year $_{t}$ are vectors of industry and year dummies, respectively, where $j$ is a one-digit SIC.

Table 3 Panel A shows results from ordinary least squares regressions for Payout Ratio as the dependent variable. ${ }^{13}$ For model 3A1, we find the expected negative relationship between Payout Ratio and ETR, at the 10\% level. In Panel B, for Dividend Yield (3B1), the coefficient for ETR is also negative, but it is significant at the 5\% level. Therefore, our cross-sectional results are not dependent upon our measure of dividends.

As shown in Table 2, 79\% of insiders have ETRs of either $0 \%$ or $30 \%$. Therefore, we run some additional models shown below using our dummies Insider ETR=0 Dummy and Insider ETR=30 Dummy.

$$
\begin{aligned}
\text { DIVIDEND }_{i t}= & \beta_{0}+\beta_{1}{\text { Insider ETR }=0 \text { Dummy }_{i t}} \\
& +\beta_{2}{\text { Insider ETR }=30 \text { Dummy }_{i t}+\beta_{3} \text { Lsize }_{i t}+\beta_{4} \text { Leverage }_{i t}} \\
& +\beta_{5} \text { Sales Growth }_{i t}+\beta_{6} \text { Outside Block }_{i t}+\text { Industry }_{j} \\
& + \text { Year }_{t}+\varepsilon_{i t}
\end{aligned}
$$

In models 3A2, 3B2 and 3B3 the Insider ETR=30 Dummy is significant. However, the Insider ETR=0 Dummy is not significant in any of the models. Apparently, insiders in the highest tax bracket avoid high-dividend stocks, while insiders in the lowest bracket do not show a strong preference. Although investors in high tax brackets will avoid high dividend stocks so as not to pay taxes, investors do not automatically choose high-dividend stocks because they do not have to pay dividends.

\footnotetext{
${ }^{13}$ Since we draw some of our observations for two years from the same firm, the observations may not be independent. To correct for the potential effect of inflated standard errors and heteroscedasticity, we use the Huber/White/Sandwich estimator. We could also control for correlated observations by using a fixed effects model. However, there was not sufficient variation in effective tax rates for the insiders between 1991 and 1992 for a fixed effects procedure to find a significant relationship even if one exists (see Zhou (2001)). In the next section, as a robustness check of our results, we use fixed effects regressions for our tests of block trades
} 
Some of our control variables show an association with dividend policy. Firms with high amounts of leverage pay statistically significantly lower dividends, as measured by both Payout Ratio and Dividend Yield. Also, there is some weak evidence that faster growing firms pay higher dividends; these results are significant at the $10 \%$ level for Payout Ratio and insignificant for Dividend Yield. These results are contrary to theory, but, as shown in the next section, coefficients become insignificant using a simultaneous equations analysis. For our sample, outside block ownership and the firm's size have no significant relationship with dividend policy.

We also include industry and year dummies. A particular industry may pay higher dividends for reasons unrelated to the effective tax rates of their shareholders. Therefore, if we leave out industry dummies, we might find a spurious correlation between dividend policy and effective tax rates. We find positive significant relationships between our dividend variable and the heavy industry and commercial services dummies. In addition, we find and a negative significant relationship between our dividend variables and the technical manufacturing dummy. The effective tax rates of insiders may decrease over time and firms may increase dividends over time for reasons unrelated to effective tax rates. Once again, if we omit a year dummy for 1992, we may find a spurious relationship between dividend payout and effective tax rates. The year dummy for our OLS regressions was insignificant in all models.

Overall, these results support our hypothesis that insiders' tax liability affects firm dividend payments. However, as we stated earlier, there are possible endogenous relationships among the variables, and, furthermore, these tests do not directly distinguish between active and passive approaches to dividend payments on the part of inside 
shareholders. Therefore, to address these problems, we perform simultaneous equations analysis and look at block trades, in the following sections.

\subsection{Simultaneous Equations}

In the previous section, we showed a relationship between insiders' effective tax rates and firm dividend payments. However, insiders’ effective tax rates, a firm’s dividend policy, insider ownership and stock price changes are most likely simultaneously determined. Clearly, the relationship between a firm's dividend and an insider's effective tax rate is affected by the firm's recent stock price performance and the insider's stock sales. For example, an insider who sells shares at a taxable profit and does not want to take on additional offsetting tax write-offs (such as additional personal debt or tax-loss selling) will be reluctant to pay dividends. In this section, we use a simultaneous equations analysis to provide additional evidence for the robustness of the relationship between effective tax rates of insiders and firms' dividend payments. To address the potential endogeneity problems, we perform two-stage least squares (2SLS) analysis. In the first stage, we use ordinary least squares regressions to obtain ETR_HAT as an estimate of ETR. We instrument ETR with the change in equity ownership in year t-1, the stock-price change of the insider's firm during year t-1, and the market value of firm equity in the beginning of year $\mathrm{t}-1$.

We report the results of the second stage regressions model given below in Panel C of Table $3 .^{14}$

\footnotetext{
${ }^{14}$ In the first stage unreported regressions, the change in equity ownership in year t-1 is negatively and significantly related to ETR, while the stock-price change of the insider's firm during year t-1 and the market value of firm equity in the beginning of year t-1 are positively and significantly related to ETR. The change in equity ownership in year t-1, the stock-price change of the insider's firm during year t-1, and the market value of the firm's equity in the beginning of year t- 1 are all insignificant when regressed on dividend yield and payout ratio, respectively. The models with dividend yield and payout ratio as dependent variable are also rejected by an F-test.
} 


$$
\begin{aligned}
\text { DIVIDEND }_{i t}= & \beta_{0}+\beta_{1} \text { ETR_HAT }_{i t}+\beta_{2} \text { Lsize }_{i t}+\beta_{3} \text { Leverage }_{i t} \\
& +\beta_{4} \text { Sales Growth } \\
& +\beta_{5} \text { Outside Block }_{i t}+\text { Industry }_{j} \\
& + \text { Year }_{t}+\varepsilon_{i t} \text { (3) }
\end{aligned}
$$

The relationship between insider effective tax rates and dividend payout, although weaker, remains negative and statistically significant for both Payout Ratio (model 3C1) and Dividend Yield (model 3C3). For some sample points ETR_HAT is below 0\% or above $30 \%$. Since this is not feasible, we re-run the second stage after changing all negative ETR_HAT to $0 \%$ and ETR_HAT above 30\% to 30\% (models 3C2 and 3C4). The results do not change materially. Also, more consistent with theory, our growth proxy becomes insignificant, and our outside block variable, though not quite significant, is stronger.

\subsection{Block Trade Tests}

Our results in the previous section are consistent with the theory that shareholders form tax-induced clienteles. In this section, we test the hypothesis that insiders gain private benefits of control by actively managing dividend policy for personal tax reasons. We are interested in whether dividend payment changes after a block trade are attributable to a difference in the effective tax rates of the exchanging blockholders. Specifically, we hypothesize that when blocks are traded to investors with lower effective tax rates, the firm's dividends should increase in the years following the block trade. Also, when blocks are traded to higher effective tax rate investors, dividends should decrease.

Since dividend yield is affected by stock prices and dividend payout is affected by net income, these results are possible even if all the firms in our sample increased their dividends. We should point out that we do not know the exact tax rate of the block purchasers. We do, however, know that inside sellers with zero effective rates sell to buyers with as high or higher tax rates. Therefore, we assume the buyers, on average, have a 
higher tax rate. In addition, since we know that sellers with $30 \%$ effective tax rates sell to buyers with the same or lower tax rate, we also assume that the buyers in this case have, on average, a lower effective tax rate. Hence, if taxes matter, we expect that dividends should:

(1) decrease, on average, when an insider with a zero tax rate sells a block, and

(2) increase when an insider with a $30 \%$ effective tax rate sells a block.

To test this, we run the following fixed effect regression model, ${ }^{15}$

$$
\begin{aligned}
\text { DIVIDEND }_{i t}= & \beta_{0}+\beta_{1} \text { InsiderETR } 0 \text { Sell Dummy }_{i t}+\beta_{2} \text { InsiderETR } \text { 30 Sell Dummy } \\
& \\
& +\beta_{3} \text { Lsize }_{i t}+\beta_{4} \text { Leverage }_{i t}+\beta_{5} \text { Sales Growth }_{i t}+\beta_{6} \text { Outside Block }_{i t} \\
& + \text { Firm }_{i}+\text { Year }_{t}+\varepsilon_{i t}
\end{aligned}
$$

As shown in Table 4, there is support for (1). The coefficient for the Insider ETR=0 Sell Dummy is negative and significant at the 5\% level for the Dividend Yield (model 4a) and Dividend Payout (model 4b) fixed effects regressions. However, we do not find support for (2): The coefficient for the Insider ETR=30 Sell Dummy is insignificant in both regressions.

We are particularly interested in our logit results with Dividend Decrease and Dividend Increase as the dependent variables.

$$
\begin{aligned}
\text { DIVIDEND }_{i t}= & \beta_{0}+\beta_{1} \text { InsiderETR }=0 \text { Sell Dummy } \\
& +\beta_{2} \text { InsiderETR }_{i t} \\
& +\beta_{5} \text { Sales Sell Dummy }_{i t}+\beta_{3} \text { Lsize }_{i t}+\beta_{4} \text { Leverage }_{i t}+\beta_{6} \text { Outside Block }_{i t}+\text { Industry }_{j} \\
& + \text { Year }_{t}+\varepsilon_{i t}
\end{aligned}
$$

As we stated before, it is commonly accepted that firms are very reluctant to reduce dividends per share. We therefore believe a positive relationship between Dividend Decrease and the ETR=0 Sell Dummy is strong evidence that controlling shareholders 
adjust dividend policy to suit their tax-induced preferences. For our logit results, with Dividend Decrease as the dependent variable (model 4c), the ETR=0 Sell Dummy has the expected positive sign and is significant at the $5 \%$ level. Also in model $4 \mathrm{~d}$, we find a significant (10\%) negative relationship between ETR=0 Sell Dummy and the Dividend Increase dummy. We interpret these results as providing evidence that shareholders will lower dividends and not increase dividends to avoid paying taxes.

Finally, ETR=30 Sell Dummy is not significant for the Dividend Decrease (4c) or Dividend Increase (4d) regressions. Assuming that blockholders, with effective tax rates of $30 \%$, do not sell primarily to buyers, with effective tax rates of $30 \%$, these results imply that shareholders don't routinely increase dividends because they don't have to pay taxes on them. These results are consistent with our OLS results. Also, as discussed by Black (1976), since managers are reluctant to cut dividends, they should also be reluctant to make an unsustainable dividend increase, simply because they won't be taxed on the dividend. Overall, these results demonstrate the importance of distinguishing the effective tax rates of the inside sellers and provide evidence that effective tax rates impact the dividend decision.

To illustrate the advantage of using each insider's actual personal effective tax rates, (rather than average individual rates), similar to BHS, we also classify block traders into two groups: individuals and institutions. Although we do not report our results we do not find any significant influence of insider-controlled firms on dividend policy, as measured by Dividend Yield, Payout Ratio, Dividend Decrease, or Dividend Increase. Since insiders' effective tax rates vary from $0 \%$ to $30 \%$ (as we show in Table 2), the tests do not have any power. Also, we find the Institutional Dummy is weakly negatively

\footnotetext{
${ }^{15}$ For the Logit model we use firm dummies rather than industry dummies, otherwise it is identical to the
} fixed effects model. 
significant at the $10 \%$ level for Dividend Yield and Payout Ratio. This negative sign is contrary to the predictions of Allen and Michaely (2003), who suggest that firms pay dividends to attract institutional investors.

\section{$5 \quad$ Conclusions}

Numerous theoretical and empirical papers have examined the relationship between effective tax rates of shareholders and firm dividend policy. The empirical studies have used various proxies for the effective tax rate of investors because personal tax rate information is generally not available. We have collected the actual effective tax rate of shareholders, which allows us to directly test the influence of the effective tax rates of investors on the dividend policy of the firm. We conclude that insiders, who have sufficient power, set firm dividends to reduce their personal tax burden. 


\section{References}

Allen, F. and R. Michaely, 2003, Payout Policy, North Holland Handbook of Economics, edited by George Constantinides, Milton Harris, and Rene Stulz (Amsterdam, Elsevier-North Holland).

Barclay, M.J., C.G. Holderness, and D.P. Sheehan, 2007, “Dividends and corporate shareholders”, Review of Financial Studies, forthcoming.

Black, F., 1976, “The dividend puzzle,” Journal of Portfolio Management, 2, 5-8.

Black, F. and M. Scholes, 1974, "The effects of dividend yield and dividend policy on common stock prices and returns, Journal of Financial Economics, 1, 1-22.

Brennan, M., 1970, “Taxes, market valuation, and corporate financial policy,” National Tax Journal, 417-427.

Brennan, M.J. and A.V. Thakor, 1990, "Shareholder preferences and dividend policy," Journal of Finance, 45, 993-1010.

Dybvig, P.H. and S.A. Ross, 1986, “Tax clienteles and asset prices,” Journal of Finance, 41, 751-762.

Faccio, M., L.H.P. Lang and L. Young, 2002, “Dividends and expropriation,” American Economic Review, 91, 54-78.

Graham J.R. and A. Kumar, 2006, “Do dividend clienteles exist? Evidence on dividend preferences of retail investors”, Journal of Finance, 61, 1305-1336.

Hubbard, J., and R. Michaely, 1997, Do investors ignore dividend taxation? A reexamination of the citizens utilities case”, Journal of Financial \& Quantitative Analysis, 32, 117-136.

Jensen, M. C., 1986, “Agency costs of free cash flow, corporate finance, and takeovers,” American Economic Review, 76, 323-329.

Lie, E and H. Lie, 1999, “The role of personal taxes in corporate decisions: An empirical analysis of share repurchases and dividend," Journal of Financial and Quantitative Analysis, 533-552.

Lodin, S.O., G. Lindencrona, P. Melz, and C. Silfverberg, 1999, Income Taxation: A Handbook in Taxlaw (Inkomsttskatt: en läro- och handbok $i$ skatterätt), Studentlitteratur, Lund.

Miller, M., and F. Modigliani, 1961, "Dividend policy, growth, and the valuation of shares,” Journal of Business, 34, 411-433. 
Miller, M., and M. Scholes, 1978, “Dividend and taxes,” Journal of Financial Economics, 6, 333-364.

Perez-Gonzales, F., 2003, "Large shareholders and dividends: Evidence from U.S. tax reforms”, working paper Columbia University.

Peterson, P.P., Peterson, D.R., and J.S. Ang, 1985, "Direct evidence of the marginal rate of taxation on dividend income,” Journal of Financial Economics, 14, 267-282.

Shleifer, A. and R.W. Vishny, 1986, “Large Shareholders and Corporate Control,” Journal of Political Economy, 94, 461-488.

Sundqvist, S-I., 1991 to 1993, Owners and Power in Sweden's Listed Companies (Ägarna och Makten), Dagens Nyheters Förlag, Stockholm.

Sundin, A. and S-I. Sundqvist, 1994 and 1995, Owners and Power in Sweden's Listed Companies (Ägarna och Makten), Dagens Nyheters Förlag, Stockholm.

Zhou, X., 2001, Understanding the determinants of managerial ownership and the link between ownership and performance: comment”, Journal of Financial Economics, $62,559-571$. 
Table 1

Swedish Tax Rates on Dividends and Capital Gains for Different Investors 1991-1995

\begin{tabular}{|c|c|c|c|c|c|c|}
\hline & \multicolumn{2}{|c|}{ Insiders $^{\mathrm{a}}$} & \multicolumn{2}{|c|}{ Corporations $^{\mathrm{a}}$} & \multicolumn{2}{|c|}{ Financial Institutions ${ }^{\mathrm{b}}$} \\
\hline & Dividends & Capital gains & Dividends ${ }^{\mathrm{C}}$ & Capital gains & Dividends $^{\mathrm{d}}$ & Capital gains \\
\hline 1991 & $30 \%$ & $30 \%$ & $0 \%$ or $30 \%$ & $30 \%$ & $0-30 \%$ & $0 \%$ \\
\hline 1992 & $30 \%$ & $30 \%$ & $0 \%$ or $30 \%$ & $30 \%$ & $0-30 \%$ & $0 \%$ \\
\hline 1993 & $30 \%$ & $30 \%$ & $0 \%$ or $30 \%$ & $30 \%$ & $0-30 \%$ & $0 \%$ \\
\hline $1994^{\mathrm{e}}$ & $0 \%$ & $12.5 \%$ & $0 \%$ or $28 \%$ & $28 \%$ & $0-28 \%$ & $0 \%$ \\
\hline 1995 & $30 \%$ & $30 \%$ & $0 \%$ or $28 \%$ & $28 \%$ & $0-28 \%$ & $0 \%$ \\
\hline
\end{tabular}

${ }^{\mathrm{a}}$ For Insiders and Corporations dividends and capital gains are taxable. For Insiders and Corporations capital losses and other financial costs (paid interests etc) are deductible as long as there is no fiscal deficit.

${ }^{\mathrm{b}}$ Open and Closed End Investment Funds

${ }^{\text {c } C o r p o r a t i o n s ~ p a y ~} 30 \%$ tax on received dividends unless they hold more than $25 \%$ of the voting rights in the firm. If they hold more than $25 \%$ of the voting rights, dividends are tax exempt. Capital gains are taxed at the corporate tax rate independent of ownership stake.

${ }^{\mathrm{d}}$ Dividends received by investment funds are taxable. However, received dividends are tax exempt if they are transferred to the owners of the financial institution.

${ }^{\mathrm{e}}$ During 1994 there were restrictions on how much the firms could distribute as dividends. It was evident that the Social Democrats would win the 1994 election and reverse the zero dividend tax introduced by the Conservative government January 1, 1994. 
Table 2

\section{Descriptive Statistics}

The sample used in this study consists of Swedish firms listed on the Stockholm Stock Exchange's A-list 1991-1992. $\mathrm{N}=110$. The sample is collected based on the availability of the largest insider's (most voting rights) tax sheet. In this table we report Descriptive statistics. Dividend Yield is defined as total dividends paid during the year divided by the market value of equity at the beginning of the year. Payout Ratio is defined as total dividends paid during the year divided by accounting earnings. If dividends are paid but accounting earnings are negative, Payout Ratio is set to one. If dividends are larger than accounting earnings, Payout Ratio is set to one. ETR is the largest insider's effective tax rate on the dividends received from the firm, ceteris paribus (ETR=0\% for 31 ( $28 \%$ ) observations, $0<\mathrm{ETR}<30$ for $23(21 \%)$ observations, and ETR=0.3 for 56 observations (51\%)). Size is the book value of total assets in Million SEK. Leverage is equal to the book value of long term debt divided by the book value of total assets. Sales Growth is equal to the annual change in the firm's total sales. Votes is equal to the vote fraction controlled by the coalition Outside Block is equal to one if there is an outsider with at least 10 percent of the votes, and zero otherwise. Votes is equal to the vote fraction controlled by the largest insider coalition.

\begin{tabular}{lccccccc}
\hline & Mean & Min & $25 \%$ & Median & $75 \%$ & Max & Std dev \\
\hline Dividend Yield & 0.0355 & 0 & 0.0215 & 0.0359 & 0.0483 & 0.1029 & 0.0219 \\
Payout Ratio & 0.2718 & 0 & 0.0787 & 0.1526 & 0.2799 & 1.0000 & 0.3164 \\
ETR & 0.1737 & 0 & 0 & 0.3000 & 0.3000 & 0.3000 & 0.1373 \\
Size & 19244 & 165 & 1091 & 4017 & 12117 & 485333 & 63710 \\
Leverage & 0.3024 & 0.0001 & 0.1378 & 0.2731 & 0.4277 & 0.9164 & 0.1921 \\
Sales Growth & 0.0687 & -0.9217 & -0.0637 & 0.0000 & 0.0650 & 2.6632 & 0.4891 \\
Outside Block & 0.5909 & 0 & 0 & 1.0000 & 1.0000 & 1.0000 & 0.4939 \\
Votes & 0.4099 & 0.012 & 0.2140 & 0.4005 & 0.5650 & 0.9440 & 0.2548 \\
\hline
\end{tabular}


Table 3

OLS and 2SLS regressions with Dividend Yield and Payout Ratio, respectively, as dependent variable The sample used in this study consists of Swedish firms listed on the Stockholm Stock Exchange's A-list, 1991-1992. $N=110$. The sample is collected based on the availability of the largest insider's (most voting rights) tax form. In panel A and B we report OLS regression with Dividend Yield and Payout Ratio as dependent variable, respectively. Dividend Yield is defined as total dividends paid during the year divided by the market value of equity at the beginning of the year. Payout Ratio is defined as total dividends paid during the year divided by accounting earnings. If dividends are paid but accounting earnings are negative, Payout Ratio is set to one. If dividends are larger than accounting earnings, Payout Ratio is set to one. In Panel C we report 2SLS regressions where ETR_HAT is the estimated ETR from the first stage regression. ETR is the largest insider's effective tax rate on the dividends received from the firm, ceteris paribus. The change in equity ownership in year $\mathrm{t}-1$, the stock-price change of the insider's firm during year t-1, and the market value of firm equity in the beginning of year $\mathrm{t}-1$ are used as instruments. Coefficients are reported with t-values in parenthesis. t-values are adjusted for heteroscedasticity and correlated observations with the Huber-White Sandwich estimator of variance. ***, **, and * denote significance at the 1\%, 5\%, and $10 \%$ level respectively. $E T R=30 \%$ Dummy is equal to one if the largest insider has a $30 \%$ effective tax rate on dividends received from the firm, and zero otherwise. $E T R=0 \%$ Dummy is equal to one if the largest insider has a $0 \%$ effective tax rate on dividends received from the firm, and zero otherwise. Lsize is the natural logarithm of the book value of total assets. Leverage is equal to the book value of long term debt divided by the book value of total assets. Sales Growth is equal to the annual change in the firm's total sales. Outside Block is equal to one if there is an outsider with at least 10 percent of the votes, and zero otherwise.

Panel A: OLS regressions with Payout Ratio as dependent variable Model 3A1 3A2 3A3

\begin{tabular}{|c|c|c|c|}
\hline Dependent Variable & Payout Ratio & Payout Ratio & Payout Ratio \\
\hline ETR & $\begin{array}{l}-0.4182 \\
(-1.84)^{*}\end{array}$ & & \\
\hline$E T R=30 \%$ Dummy & & $\begin{array}{l}-0.1236 \\
(-1.90)^{*}\end{array}$ & $\begin{array}{c}-0.0959 \\
(-1.21)\end{array}$ \\
\hline$E T R=0 \%$ Dummy & & & $\begin{array}{c}0.0359 \\
(0.48)\end{array}$ \\
\hline Lsize & $\begin{array}{c}0.0006 \\
(0.03)\end{array}$ & $\begin{array}{c}0.0045 \\
(0.21)\end{array}$ & $\begin{array}{c}0.0031 \\
(0.14)\end{array}$ \\
\hline Leverage & $\begin{array}{c}-0.4727 \\
(-3.32)^{* * *}\end{array}$ & $\begin{array}{c}-0.4526 \\
(-3.18)^{* * *}\end{array}$ & $\begin{array}{c}-0.4666 \\
(-3.19)^{* * *}\end{array}$ \\
\hline Sales Growth & $\begin{array}{l}0.1237 \\
(1.72)^{*}\end{array}$ & $\begin{array}{l}0.1294 \\
(1.76)^{*}\end{array}$ & $\begin{array}{l}0.1246 \\
(1.70)^{*}\end{array}$ \\
\hline Outside Block & $\begin{array}{c}0.0257 \\
(0.42)\end{array}$ & $\begin{array}{c}0.0247 \\
(0.41)\end{array}$ & $\begin{array}{c}0.0257 \\
(0.42)\end{array}$ \\
\hline Year Dummy & Yes & Yes & Yes \\
\hline Industry Dummies & Yes & Yes & Yes \\
\hline Adj $R^{2}$ & 0.264 & 0.264 & 0.258 \\
\hline
\end{tabular}


Panel B: OLS regressions with Dividend Yield as dependent variable Model 3B1 3B2 3B3

\begin{tabular}{|c|c|c|c|c|}
\hline Dependent Variable & Dividend Yield & \multicolumn{2}{|c|}{ Dividend Yield } & Dividend Yield \\
\hline$E T R$ & $\begin{array}{c}-0.0338 \\
(-1.99)^{* *}\end{array}$ & \multirow{2}{*}{\multicolumn{2}{|c|}{$\begin{array}{c}-0.0126 \\
(-2.60)^{* *}\end{array}$}} & \\
\hline$E T R=30 \%$ Dummy & & & & $\begin{array}{c}-0.0145 \\
(-2.64)^{* *}\end{array}$ \\
\hline$E T R=0 \%$ Dummy & & & & $\begin{array}{c}-0.0007 \\
(-0.12)\end{array}$ \\
\hline Lsize & $\begin{array}{c}0.0020 \\
(1.21)\end{array}$ & \multicolumn{2}{|c|}{$\begin{array}{c}0.0025 \\
(1.57)\end{array}$} & $\begin{array}{c}0.0018 \\
(1.10)\end{array}$ \\
\hline Leverage & $\begin{array}{l}-0.0219 \\
(-1.86)^{*}\end{array}$ & \multicolumn{2}{|c|}{$\begin{array}{c}-0.0189 \\
(-1.65)\end{array}$} & $\begin{array}{l}-0.0229 \\
(-1.84)^{*}\end{array}$ \\
\hline Sales Growth & $\begin{array}{l}0.0036 \\
(1.00)\end{array}$ & \multicolumn{2}{|c|}{$\begin{array}{l}0.0041 \\
(1.20)\end{array}$} & $\begin{array}{c}-0.0011 \\
(-0.26)\end{array}$ \\
\hline Outside Block & $\begin{array}{c}-0.0004 \\
(-0.10)\end{array}$ & \multicolumn{2}{|c|}{$\begin{array}{c}-0.0001 \\
(-0.02)\end{array}$} & $\begin{array}{l}-0.0027 \\
(-0.67)\end{array}$ \\
\hline Year Dummy & Yes & \multicolumn{2}{|c|}{ Yes } & Yes \\
\hline Industry Dummies & Yes & \multicolumn{2}{|c|}{ Yes } & Yes \\
\hline $\operatorname{Adj~R}^{2}$ & 0.083 & \multicolumn{2}{|c|}{0.108} & 0.097 \\
\hline \multicolumn{5}{|c|}{$\begin{array}{l}\text { Panel C: } 2 \text { SLS regressions (in 3C2 and 3C4 ETR_HAT has been set to } 0 \text { if ETR_HAT }<0 \text { and to } 0.3 \text { if } \\
\text { ETR_HAT }>0.3 \text {. }\end{array}$} \\
\hline Model & 3C1 & $3 \mathrm{C} 2$ & $3 \mathrm{C} 3$ & $3 \mathrm{C} 4$ \\
\hline Dependent Variable & Payout Ratio & Payout Ratio & Dividend Yield & Dividend Yield \\
\hline$E T R \_H A T$ & $\begin{array}{l}-3.2350 \\
(-1.83)^{*}\end{array}$ & $\begin{array}{l}-2.7459 \\
(-1.88)^{*}\end{array}$ & $\begin{array}{l}-0.2219 \\
(-1.94)^{*}\end{array}$ & $\begin{array}{l}-0.2068 \\
(-2.20)^{*}\end{array}$ \\
\hline Lsize & $\begin{array}{c}0.0511 \\
(1.07)\end{array}$ & $\begin{array}{l}0.0423 \\
(1.14)\end{array}$ & $\begin{array}{l}0.0054 \\
(1.82)^{*}\end{array}$ & $\begin{array}{c}0.0051 \\
(2.11)^{* *}\end{array}$ \\
\hline Leverage & $\begin{array}{l}-0.2363 \\
(-0.88)\end{array}$ & $\begin{array}{l}-0.2997 \\
(-1.30)\end{array}$ & $\begin{array}{l}-0.0067 \\
(-0.39)\end{array}$ & $\begin{array}{c}-0.0091 \\
(0.61)\end{array}$ \\
\hline Sales Growth & $\begin{array}{c}0.1040 \\
(0.95)\end{array}$ & $\begin{array}{l}0.1040 \\
(1.23)\end{array}$ & $\begin{array}{c}0.0022 \\
(0.35)\end{array}$ & $\begin{array}{c}0.0021 \\
(0.38)\end{array}$ \\
\hline Outside Block & $\begin{array}{c}0.1747 \\
(1.43)\end{array}$ & $\begin{array}{c}0.1485 \\
(1.42)\end{array}$ & $\begin{array}{c}0.0096 \\
(1.09)\end{array}$ & $\begin{array}{c}0.0087 \\
(1.30)\end{array}$ \\
\hline Year Dummy & Yes & Yes & Yes & Yes \\
\hline Industry Dummies & Yes & Yes & Yes & Yes \\
\hline Adj $R^{2}$ & 0.285 & 0.283 & 0.084 & 0.101 \\
\hline
\end{tabular}


Table 4

Block Trade Regressions with Dividend Yield, Payout Ratio, Dividend Decrease Dummy and Dividend Increase Dummy respectively, as dependent variable

The sample used in this study consists of Swedish firms listed on the Stockholm Stock Exchange's A-list 1991-1992. The sample is collected based on the availability of the largest insider's (most voting rights) tax sheet. In this table we report fixed effects regressions for dependent variables Dividend Yield and Payout Ratio and logit regressions for dependent variables Dividend Decrease Dummy and Dividend Increase Dummy. For the firms in the 1991 and/ or 1992 sample, data are collected for the years 1988-1995. The number of firms is 59 and the number of firm years is 427. Coefficients are reported with heteroscedasticity robust t-values in parenthesis. ***,**, and * denote significance at the $1 \%, 5 \%$, and $10 \%$ level respectively. Dividend Yield is defined as total dividends paid during the year divided by the market value of equity at the beginning of the year. The Dividend Decrease Dummy is equal to one for all years after a dividend decrease until dividends are as high as or higher than before the decrease, and zero otherwise. The Dividend Increase Dummy is equal to one the years dividends increase, and zero otherwise. Payout Ratio is defined as total dividends paid during the year divided by accounting earnings. If dividends are paid but accounting earnings are negative, Payout Ratio is set to one. If dividends are larger than accounting earnings, Payout Ratio is set to one. In this table we report logit regressions with indicator variables for a dividend decrease or increase, respectively, as dependent variables. Insider $E T R=0$ Sell Dummy is equal to one the years after an insider with a zero effective tax rate on dividends sold his/ her block, and zero otherwise (11 such block trades). Insider $E T R=30$ Sell Dummy is equal to one the years after an insider with a 30\% effective tax rate on dividends sold his/ her block, and zero otherwise (6 such block trades). Lsize is the natural logarithm of the book value of total assets. Leverage is equal to the book value of long term debt divided by the book value of total assets. Sales Growth is equal to the annual change in the firm's total sales. Outside Block is equal to one if there is an outsider with at least 10 percent of the votes, and zero otherwise.

\begin{tabular}{lcccc}
\hline Model & 4a & 4b & 4c & 4d \\
\hline Regression Type & Fixed Effects & Fixed Effects & Logit & Logit \\
\hline Dependent & Dividend Yield & Payout Ratio & Dividend Decrease & $\begin{array}{c}\text { Dividend Increase } \\
\text { Variable }\end{array}$ \\
Insider ETR=0 & -0.0154 & & Dummy & -1.008 \\
Sell Dummy & $(-2.50)^{* *}$ & -0.3459 & 3.2196 & $(-1.78)^{*}$ \\
Insider ETR $=30$ & -0.0053 & $(-2.33)^{* *}$ & $(2.49)^{* *}$ & -0.2328 \\
Sell Dummy & $(-0.62)$ & 0.0052 & 1.5601 & $(-0.58)$ \\
Lsize & 0.0096 & $(0.03)$ & $(1.07)$ & 0.1216 \\
& $(2.19)^{* *}$ & 0.0377 & -0.2911 & $(1.35)$ \\
Leverage & -0.0517 & $(0.62)$ & $(-1.79)^{*}$ & -4.2650 \\
Sales Growth & $(-4.74)^{* * *}$ & -0.2768 & 3.2029 & $(-5.19)^{* * *}$ \\
Outside Block & -0.0035 & $(-1.17)$ & $(2.51)^{* *}$ & -0.0330 \\
Year Dummies & $(-1.01)$ & -0.0283 & -0.0447 & $(-0.11)$ \\
Industry Dummies & 0.0213 & $(-0.84)$ & $(-0.10)$ & 0.3118 \\
Adj R & $(1.91)^{*}$ & 0.1427 & -0.2023 & $(0.008)$ \\
CorrectlyClassified & Yes & $(1.01)$ & $(-0.32)$ & Yes \\
\hline
\end{tabular}

